\title{
Penerapan Sistem Pakar untuk Diagnosa Penyakit dan Hama Tanaman Cabai dengan Metode Forward Chaining
}

\author{
Application of Expert System to Diagnose Diseases and Pests of Chilli \\ Plants Using Forward Chaining Method \\ Maulida Ayu Fitriani ${ }^{1}$, Dany Candra Febrianto ${ }^{2}$ \\ ${ }^{1}$ Program Studi S1 Teknik Informatika, Fakultas Teknik dan Sains, Universitas \\ Muhammadiyah Purwokerto \\ ${ }^{2}$ Program Studi Magister Teknologi Informasi, Universitas Gadjah Mada \\ ${ }^{1}$ maulidaayuf@gmail.com
}

\begin{abstract}
ABSTRAK
Cabai (Capsium annum L.) adalah komoditas sayuran yang banyak mendapatkan perhatian karena memiliki nilai ekonomis yang cukup tinggi kebutuhan cabai semakin lama semakin meningkat setiap tahunnya sejalan dengan berkembangnya sebuah industri yang membutuhkan bahan baku cabai. Cara perawatan yang salah atau tidak sesuai dengan standart yang ada, dapat mengakibatkan tanaman cabai rentan terkena hama penyakit dan dapat mengakibatkan hasil panen tidak bisa maksimal, hasil penjualan yang rendah dan bahkan bisa mengakibatkan gagal panen. Hama utama pada tanaman cabai antara lain ulat hama ulat grayak kutu daun, thrips, tungau, lalat buah hama tersebut yang bisa mengakibatkan tanaman cabai terkena penyakit. Pada makalah ini disarankan menggunakan Sistem Pakar dengan metode Forward Chaining guna memberikan saran atau pertimbangan kepada petani untuk diagnosis penyakit atau hama serta penangannya. Metode Forward Chaining berfungsi sebagai mesin inferensi berdasarkan fakta-fakta yang ada. Pada makalah ini doagnosa penyakit pada cabai sudah menggunakan sistem pakar untuk memudahkan memberikan informasi berupa kesimpulan tentang penyakit tanamann cabai sehingga hal ini bisa menjadi acuan.
\end{abstract}

Kata kunci : Penyakit Cabai, Sistem Pakar, Forward Chaining

\begin{abstract}
Chili (Capsium annum L.) is a vegetable commodity that is gaining a lot of attention because it has a high economic value. The need for chili is increasing every year in line with the development of an industry that requires chili raw materials. The way of treatment that is wrong or not in accordance with existing standards, can result in chili plants susceptible to disease pests and can result in yields that cannot be maximized, low sales results and can even result in crop failure. The main pests on chili plants include caterpillar pests caterpillars, leaf aphids, thrips, mites, fruit flies that can cause chili plants affected by disease. In this paper it is recommended to use the Expert System with the Forward Chaining method to provide advice or consideration to farmers for the diagnosis of diseases or pests and their handling. The Forward Chaining method functions as an inference engine based on facts. In this paper, the disease in chili has used an expert system to make it easy to provide information in the form of conclusions about the disease of chillies so that this can be a reference.
\end{abstract}

Keywords: Chili Disease, Expert System, Forward Chaining 


\section{PENDAHULUAN}

Ada banyak teknologi yang mampu mengadopsi proses dan cara berfikir manusia, salah satunya adalah sistem pakar. Sistem pakar merupakan salah satu bagian dari kecerdasan buatan yang mengandung pengetahuan dan pengalaman satu atau banyak pakar yang di transformasikan kedalam suatu area pengetahuan tertentu sehingga dapat membantu banyak orang dalam memecahkan berbagai macam masalah yang bersifat spesifik, teremasuk untuk diagnosa penyakit pada tanaman cabai.

Cabai (Capsium annum L.) merupakan komoditas sayuran yang banyak mendapatkan perhatian karena memiliki nilai ekonomis yang cukup tinggi kebutuhan cabai semakin lama semakin meningkat setiap tahunnya sejalan dengan tingkat konsumsi dan berkembangnya banyak industri yang membutuhkan bahan baku cabai. Tanaman ini menjadi salah satu jenis tanaman yang sangat dibutuhkan oleh semua orang di Indonesia karena kultur penduduk Indonesia menyukai makanan pedas. Beberapa tahun terakhir ini sudah banyak petani yang mulai menanam cabai sebagai salah satu alternatif dalam bercocok tanam (Tim Bina Karya Tani, 2008).

Cara perawatan yang salah atau tidak sesuai dengan standar yang ada, dapat mengakibatkan tanaman cabai rentan terkena hama penyakit dan dapat mengakibatkan hasil panen tidak bisa maksimal, hasil penjualan yang rendah dan bahkan bisa mengakibatkan gagal panen. Hama utama pada tanaman cabai antara lain ulat hama ulat grayak kutu daun, thrips, tungau, lalat buah hama tersebut yang bisa mengakibatkan tanaman cabai terkena penyakit. Penyait utama pada tanaman cabai antara lain adalah busuk buah bercak daun layu fusarium penyakit virus.

Sistem pakar adalah sistem yang menerapkan pengetahuan dengan sistem terkomputerisasi pada suatu bidang pengetahuan tertentu untuk mencapai sebuah solusi dari suatu masalah pada bidang tersebut (Pratama, N. A. dkk., 2015). Sistem pakar telah banyak digunakan memecahkan masalah di berbagai bidang, seperti bidang pertanian, perbankan dan pendidikan (Indryani, A. dkk., 2017).

Penelitian sebelumnya digunakan inferensi forward chaining pada sistem pakar untuk diagnosa hama dan penyakit tanaman padi, sehingga para petani atau masyarakat dapat mendapat informasi dan pengetahuan tentang jenis hama dan penyakit apa yang menyerang tanaman padinya, tanpa harus menunggu dan mengharapkan jawaban langsung dari ahlinya (Aeni, K., 2018).

Pada Forward Chaining diperlukan suatu kumpulan rules (aturan), kemudian satu persatu aturan tersebut akan ditelusuri sampai terpenuhinya kondisi terakhir sebagai tanda penelusuran dihentikan (Rahmat, T. dkk., 2017). Pengetahuan direpresentasikan ke dalam sistem pakar dengan menggunakan data yang dipindahkan ke seluruh jaringan dari logika 'AND' dan 'OR' sampai ditentukannya sebuah objek dengan menggunakan Forward Chaining.

Forward Chaining merupakan teknik pencarian dengan menggunakan fakta yang diketahui, setelah fakta-fakta yang didapatkan, fakta kemudian dicocokkan dengan aturan IF-THEN. Bila ada aturan atau fakta yang cocok dengan bagian IF, maka aturan tersebut dieksekusi. Saat aturan yang cocok dieksekusi maka akan ada fakta baru pada bagian THEN sehingga dapat ditambahkan dalam basis data. Pencocokan dimulai dari aturan paling atas dan setiap aturan hanya bias dieksekusi satu kali (Arhami, M., 2005).

Dengan mengumpulkan pengetahuan yang berasal dari pakar atau dari literatur yaitu berupa jenis atau nama penyakit dan gejala-gejala penyakit, tahapan pembangunan sistem pakar menggunakan metode Foward Chaining inipun dimulai. Penelitian ini merupakan penelitian suatu aplikasi sistem pakar untuk memberikan 
informasi mengenai obat untuk tanaman cabai berdasar hama dan penyakit tanaman cabai berdasar dari gelaja - gejala yang muncul.

\section{METODE PENELITIAN}

\section{A. Pengumpulan Data}

Pengumpulan data dilakukan untuk memperoleh data dan informasi terkait dengan kebutuhan sistem pakar yang dibuat. Pengumpulan data untuk sistem pakar ini bersumber dari seorang penyuluh pertanian sebagai pakar dan sumber utama serta buku-buku, jurnal dan literatur lain sebagai sumber informasi tambahan.

\section{B. Pengembangan Sistem}

Tahap pengembangan sistem pakar ini menggunakan metode pengembangan sistem pakar (Expert System Development Life Cycle). Tahapan-tahapan pengembangan sistem pakar mrngacu pada penelitian terdahulu Sri Kusumadewi (Kusumadewi, S., 2003).

Pada Gambar 1 dapat dijelaskan Observasi adalah kegiatan yang dilakukan para pakar tanaman cabai lakukan untuk bisa melihat suatu gejala fisik pada tanaman cabai. Observasi akan dilakukan secara terus menurus sampai pada tahap penarikan kesimpulan dari semua fakta yang didapatkan dari pakar.

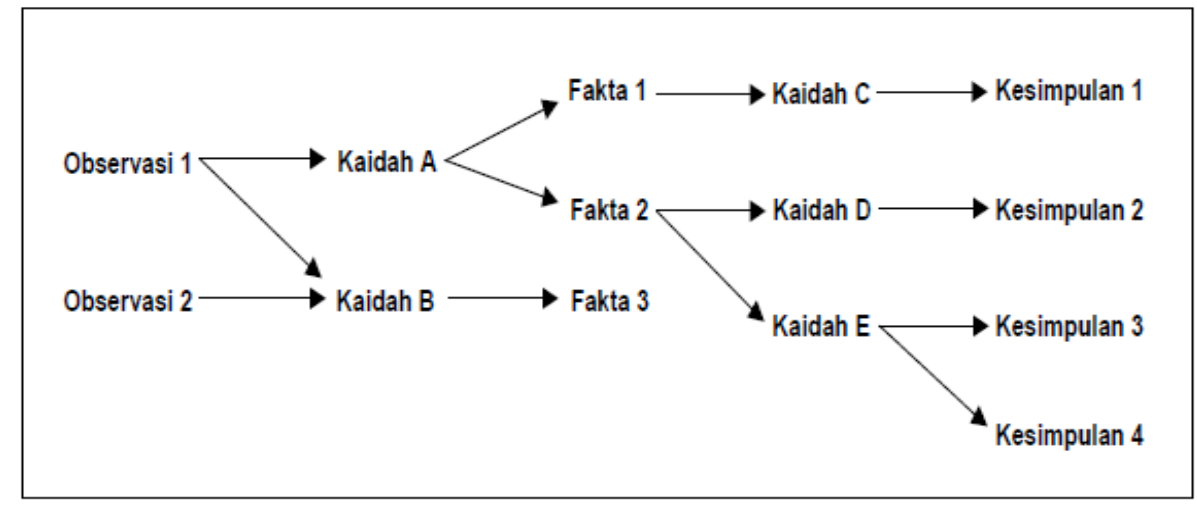

Gambar 1. Forward Chaining

\section{Spesifikasi Rancangan}

Sistem pakar ini dibuat dengan menerapkan hasil dari wawancara pada pakar yaitu pakar penyuluh pertanian. Dari hasil wawancara tersebut didapatkan pernyataanpernyataan yang akan digunakan pada sistem. Data yang digunakan dalam sistem adalah data gejala, dan data hama dan penyakit yang menyerang tanaman cabai. Data hama dan penyakit yang digunakan dalam sistem, dapat dilihat pada Tabel 1 berikut.

Tabel 1. Data Penyakit dan Hama

\begin{tabular}{cl}
\hline Kode & \multicolumn{1}{c}{ Penyakit atau Hama } \\
\hline H01 & Tripis (Thrips Parvispinus) \\
H02 & Lalat Buah (Bactrocera sp) \\
H03 & Ulat Daun \\
H04 & Kutu Kebul \\
P01 & Virus Keriting \\
P02 & Virus Kuning \\
\hline
\end{tabular}


Data obat yang digunakan dalam sistem dapat dilihat pada Tabel 2 berikut.

Tabel 2. Data Obat

\begin{tabular}{ll}
\hline Kode & \multicolumn{1}{c}{ Obat } \\
\hline O01 & Curacron, Matador, Prevathon \\
O02 & Demolish, Agrimec, Pegasus atau Sanite \\
O03 & Fipronil, Diafenthiuron \\
O04 & Amitraz, Permethrin, Fenoxycrab atau Deltrametrin \\
O05 & Cresson, Parasitoid \\
\hline
\end{tabular}

Data gejala yang digunakan dalam sistem dapat dilihat pada Tabel 3 berikut.

Tabel 3. Data Gejala

\begin{tabular}{ll}
\hline Kode & \multicolumn{1}{c}{ Gejala } \\
\hline G01 & Daun keriting \\
G02 & Tanaman menjadi kerdil \\
G03 & Daun menguning \\
G04 & Anak tulang daun menguning \\
G05 & Adanya bercak keperak-perakan pada daun \\
G06 & Adanya bercak-bercak kuning hingga kecoklatan \\
G07 & Adanya titik hitam pada pangkal buah \\
G08 & Buah cabai seperti tersiram air panas \\
G09 & Buah cabai busuk \\
G10 & Buah cabai berjatuhan \\
G11 & Daun menjadi berlubang dan merenggas \\
G12 & Daun tanaman cabai hanya tinggal efidermisnya \\
G13 & Daun menggulung \\
G14 & Warna daun belang-belang hijau tua dan muda \\
G15 & Ukuran daun lebih kecil \\
G16 & Terdapat bercak kuning pada pucuk \\
G17 & Daun cekung dan mengkerut \\
G18 & Batang tanaman berwarna kuning \\
\hline
\end{tabular}

Dari hasil diagnosa data penyakit, data gejala dan data obat maka selanjutnya terbentuk rule pakar seperti Tabel 4.

Tabel 4. Data Rule

\begin{tabular}{clcc}
\hline Kode & \multicolumn{1}{c}{ Kode Gejala } & Kode Penyakit & Kode Obat \\
\hline R01 & G03, G11, G12, G16 & $\mathrm{H} 01$ & O01 \\
R02 & G01, G06, G11, G13 & $\mathrm{H} 02$ & O02 \\
R03 & G01, G03, G05, G12, G17 & $\mathrm{H} 04$ & O02 \\
R04 & G,01, G13, G17 & $\mathrm{H} 03$ & O05 \\
R05 & G06, G10, G12 & $\mathrm{H} 04$ & O02 \\
R06 & G08, G10 & H02 & O01 \\
R07 & G01, G02, G04, G09, G10 & P01 & O03 \\
R08 & G03, G04, G06, G14, G18 & P02 & O04 \\
\hline
\end{tabular}

Dari Tabel 4 dapat dijabarkan contoh rule yang digunakan dengan sebagai berikut:

Pseudocode Rule R01 : IF Daun menguning AND Daun menjadi berlubang dan merenggas AND Daun tanaman cabai hanya tinggal efidermisnya AND Terdapat bercak kuning pada pucuk THEN HAMA: Tripis AND OBAT: Curacron, Matador, Prevathon. Penerapan rule R02 dan seterusnya pseudocode menggunakan konsep yang sama. 


\section{HASIL DAN PEMBAHASAN}

Sistem yang dibangun merupakan sistem yang berbasis desktop. User diharuskann mengisi konsultasi secara menyeluruh dan memberikan nilai kepastian pertanyaan yang tersedia. Tampilan halaman analisa pada halaman in user diminta untuk membberi jawaban ya atau tidak dari pertanyaan yang ditampilkan seperti yang ditunjukan pada Gambar 2.

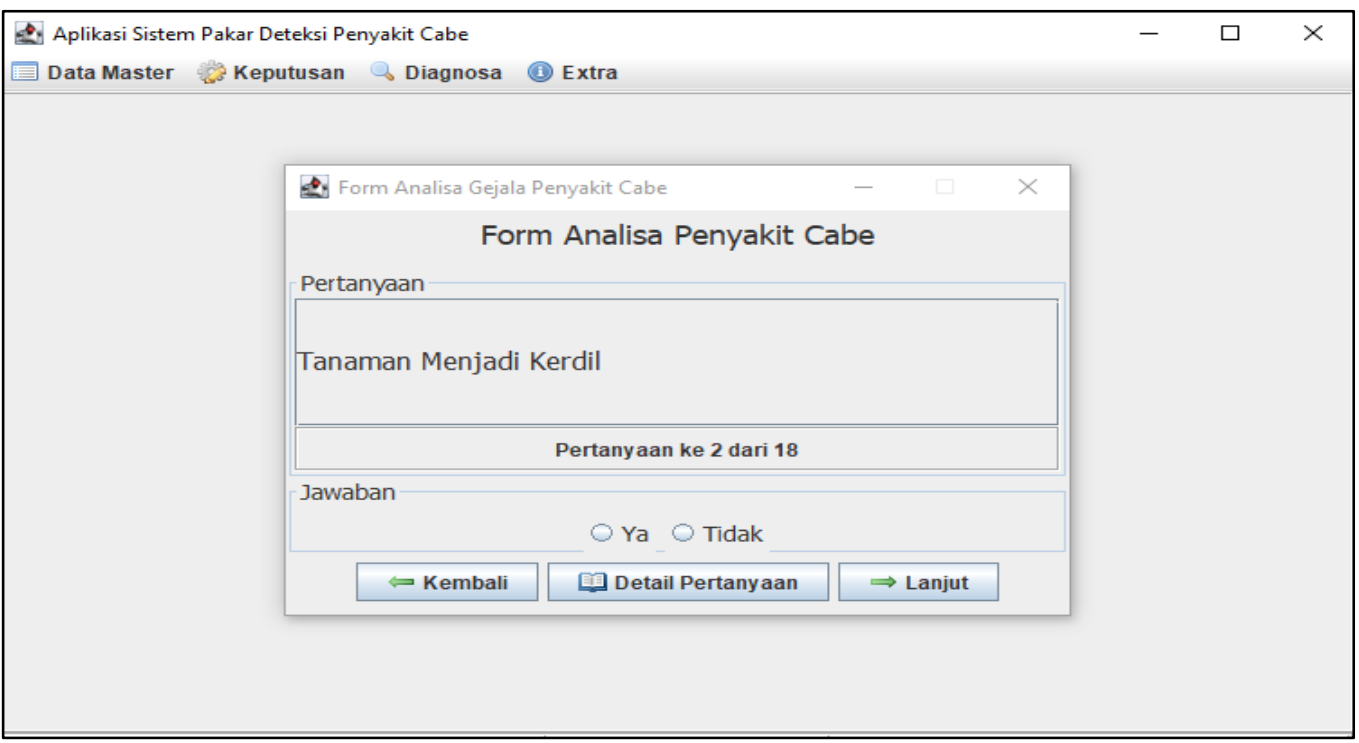

\section{Gambar 2. Tampilan Halaman Analisa}

Tampilan halaman hasil diagnosa setelah user selesai menjawab pertanyaan dari sistem seperti yang ditunjukan pada Gambar 3 .

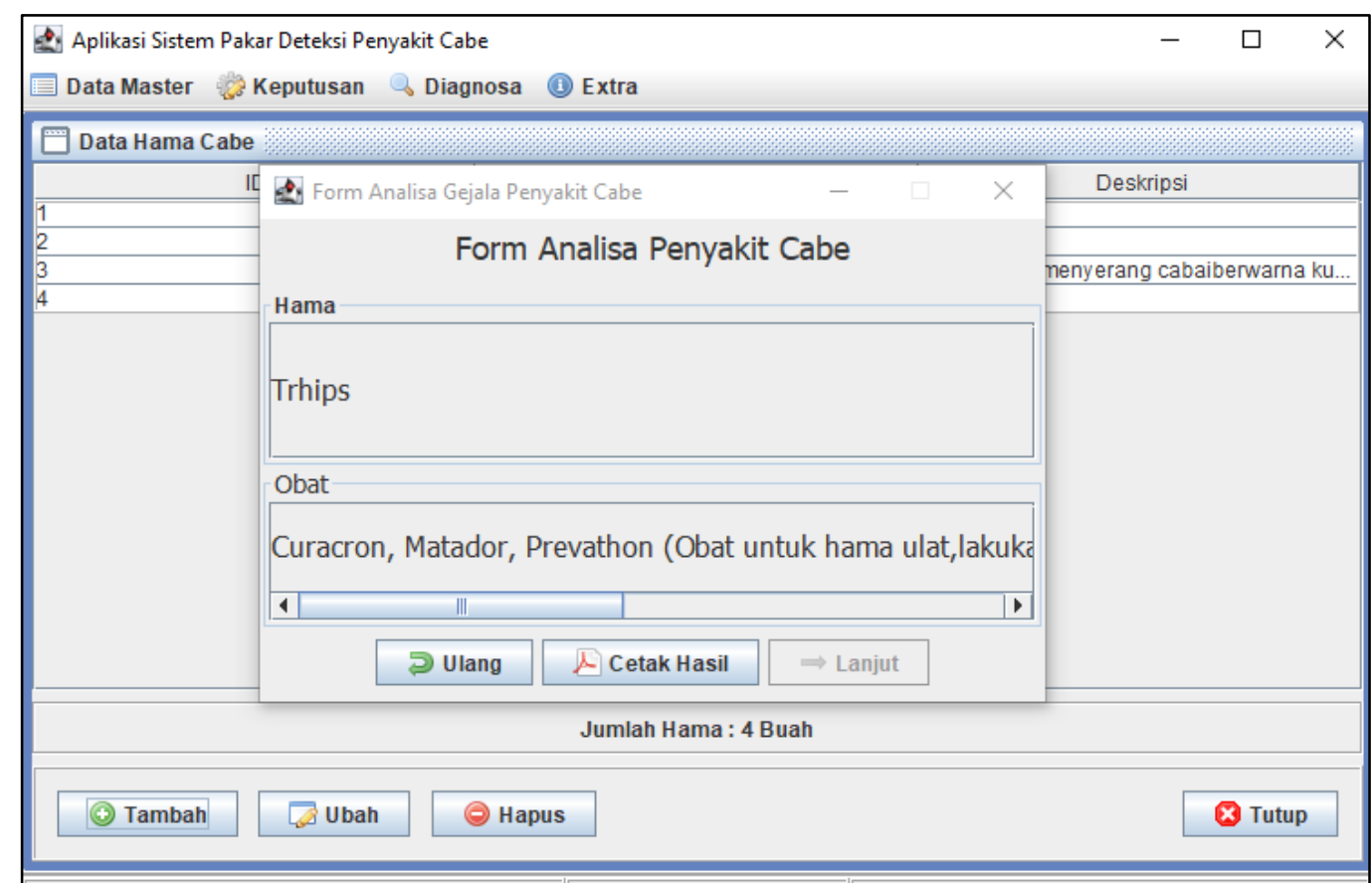

Gambar 3. Tampilan Hasil Analisa 
Penggunaan metode Forward Chaining pada sistem pakar ini karena metode tersebut mengadopsi kepastian seperti pada realita. Evaluasi dari sistem yang dibuat diantaranya adalah mengenai masih tergantungnya peran pakar pada sistem pakar ini. Dimana keputusan pakar sangat mempengaruhi hasil dari konsultasi pada sistem pakar ini.

\section{KESIMPULAN}

Dari hasil penelitian yang telah dilakukan dapat diambil kesimpulan yaitu penerapan metode Forward Chaining untuk mendiagnosa Penyakit pada cabai sudah menggunakan sistem pakar untuk memudahkan memberikan informasi berupa kesimpulan tentang penyakit tanamann cabai sehingga hal ini bisa menjadi acuan. Penelitian yang dilakukan dapat dikembangkan lagi dikemudian hari agar sistem yang dibuat dapat menjadi lebih baik lagi. Saran yang dapat disampaikan untuk pengembangan sistem pakar ini adalah penambahan fitur-fitur atau fasilitas penunjang sistem yang belum ada pada sistem ini. Penambahan kombinasi metode dalam proses penarikan kesimpulan, misalnya penggabungan antara metode Certainty Factor atau Fuzzy. Penambahan metode sebagai pembanding dari metode yang sudah dibuat, misalnya perbandingan menggunakan metode Certainty Factor atau dengan menggunakan metode Fuzzy Logic.

\section{DAFTAR PUSTAKA}

Aeni, K., 2018, Penerapan Metode Forward Chaining Pada Sistem Pakar Untuk Diagnosa Hama dan Penyakit Padi, Jurnal INTENSIF, Vol.2 No.1 February 2018 ISSN: 2580-409X (Print) / 2549-6824 (Online http://ojs.unpkediri.ac.id/index.php/intensif.

Arhami, M., 2005, Konsep Dasar Sistem Pakar, Andi, Yogyakarta.

Indryani, A. dkk., 2017, The Expert System of Children's Digestive Tract Diseases Diagnostic using Combination of Forward chaining and Certainty factor Methods, IEEE 2017 3rd International Conference on Science in Information Technology (ICSITech). DOI : 978-1-5090-5864-8/17/\$31.00.

Kusumadewi, S., 2003, Artificial intelligence (Teknik dan Aplikasinya), Graha Ilmu, Yogyakarta.

Pratama, N. A. dkk., 2015, Aplikasi Sistem Pakar Untuk Mendiagnosa Penyakit Dalam Menggunakan Metode Forward chaining dan Certainty factor Berbasis Web (Studi Kasus : Poliklinik PT. POS Indonesia Bandung), e-Proceeding of Engineering: Vol.2, No.2 Agustus 2015. ISSN : 2355-9365.

Rahmat, T. dkk., 2017, Sistem Pakar Diagnosis Penyakit Menular Pada Klinik Umum Kebon Jahe Berbasis Web Dengan Menggunakan Metode Forward Chaining, JURNAL SISFOTEK GLOBAL Vol. 7 No. 1 / Maret 2017. ISSN : 2088 -1762 .

Tim Bina Karya Tani, 2008, Pedoman Bertanam Cabai, Yrama Widya, Bandung. 